\title{
PENGARUH E-BILLING, DAN PEMAHAMAN PERPAJAKAN TERHADAP KEPATUHAN PAJAK
}

\author{
Arsyad Ardiansyah*, Mediya Destalia, M. Iqbal Harori \\ Jurusan Ilmu Administrasi Bisnis, Fakultas Ilmu Sosial dan Politik, Universitas Lampung \\ * arsyady21@gmail.com
}

\begin{abstract}
This study aims to determine the effect of e-billing, and understanding of taxation on tax compliance on taxpayers of micro, small and medium enterprises (MSMEs) registered at KPP Pratama Tanjung Karang. This type of explanatory research using a quantitative approach. The population in this study were micro, small, and medium enterprises (MSMEs) registered at KPP Pratama Tanjung Karang. The sampling technique used purposive sampling with a sample of 100 respondents. Data analysis in this study using multiple linear regression analysis with SPSS 25.0 software tools. Based on the results of research and data analysis, it shows that partially e-billing and understanding of taxation have a significant effect on tax compliance. The simultaneous test results show that e-billing, and understanding of taxation have an effect on tax compliance.
\end{abstract}

Keywords: E-billing, Tax Understanding, Tax Compliance

\begin{abstract}
ABSTRAK
Penelitian ini bertujuan untuk mengetahui pengaruh e-billing, dan pemahaman perpajakan terhadap kepatuhan pajak pada wajib pajak pelaku usaha mikro, kecil, dan menengah (UMKM) yang terdaftar di KPP Pratama Tanjung Karang. Jenis penelitian eksplanatori dengan menggunakan pendekatan kuantitatif. Populasi dalam penelitian ini adalah pelaku usaha mikro, kecil, dan menengah (UMKM) yang terdaftar di KPP Pratama Tanjung Karang. Teknik pengambilan sampel menggunakan purposive sampling dengan sampel 100 responden. Analisis data dalam penelitian ini menggunakan analisis regresi linear berganda dengan alat bantu software SPSS 25.0. Berdasarkan hasil penelitian dan analisis data menunjukkan bahwa secara parsial e-billing dan pemahaman perpajakan, berpengaruh signifikan terhadap kepatuhan pajak. Hasil pengujian secara simultan menunjukan bahwa e-billing, dan pemahaman perpajakan berpengaruh terhadap kepatuhan pajak.
\end{abstract}

Kata kunci: e-billing, pemahaman perpajakan, kepatuhan pajak 


\section{PENDAHULUAN}

Pertumbuhan ekonomi Indonesia yang sedang melakukan perkembangan pembangunan maupun perbaikan di berbagai bidang, membutuhkan sumber pendanaan dalam pelaksanaannya. sumber pendapatan suatu negara (public revenues) meliputi kekayaan alam, laba perusahaan negara (BUMN), royalti, retribusi, kontribusi, bea, cukai, dan yang terakhir pajak. Pajak memiliki peran besar dalam penerimaan Anggaran Pendapatan dan Belanja Negara (APBN) setiap tahun. Perpajakan sebagaimana yang telah dijelaskan dalam Undang-Undang No.28 Tahun 2007 Pasal 1, dimana pajak adalah sebuah iuran wajib kepada negara oleh setiap orang ataupun badan yang memiliki sifat memaksa, tetapi tetap berdasarkan dengan undang-undang dan tidak mendapat imbalan secara langsung, serta digunakan untuk kebutuhan negara dan kemakmuran rakyat. Besarnya kontribusi pajak dapat menjamin kestabilan bagi tersedianya sumber penerimaan negara (Kartikaputri, 2013).

Berdasarkan dari data tingkat anggaran pendapatan negara yang dihimpun dalam data Badan Pusat Statistik, penerimaan dari sektor pajak lebih besar dibandingkan dengan penerimaan yang bukan dari sektor pajak. Ini juga berbanding lurus dengan jumlah penerimaan pajak daerah, khususnya yang berada di provinsi Lampung. Hal tersebut dapat dilihat pada tabel 1.1 dan 1.2 sebagai berikut:

Tabel 1. Tingkat Anggaran Pendapatan Negara (Milyar Rupiah), 2016-2018

\begin{tabular}{|c|c|c|c|}
\hline Sumber Penerimaan & 2016 & 2017 & 2018 \\
\hline Penerimaan Dalam Negeri & $1.546 .946,60$ & $1.654 .746,10$ & $1.897 .643,40$ \\
\hline Penerimaan Perpajakan & $1.284 .970,10$ & $1.343 .529,80$ & $1.548 .485,00$ \\
\hline Pajak Dalam Negeri & $1.249 .499,50$ & $1.304 .316,30$ & $1.506 .436,20$ \\
\hline Pajak Penghasilan & $657.162,70$ & $761.200,30$ & $761.200,30$ \\
\hline Pajak Pertambahan Nilai & $412.213,50$ & $564.682,40$ & $564.682,40$ \\
\hline Pajak Bumi dan Bangunan & $19.443,20$ & $17.433,90$ & $17.433,90$ \\
\hline Cukai & $143.525,00$ & $155.504,80$ & $155.504,80$ \\
\hline Pajak Lainnya & $17.154,50$ & $7.614,90$ & $7.614,90$ \\
\hline Pajak Perdagangan Internasional & $35.470,70$ & $39.213,60$ & $42.048,80$ \\
\hline Bea Masuk & $32.472,10$ & $37.600,40$ & $37.600,40$ \\
\hline Pajak Ekspor & $2.998,60$ & $4.448,40$ & $4.448,40$ \\
\hline \begin{tabular}{l|l} 
& Penerimaan Bukan Pajak \\
\end{tabular} & $261.976,30$ & $311.216,30$ & $349.158,30$ \\
\hline Penerimaan Sumber Daya Alam & $64.901,90$ & $111.132,00$ & $169.196,30$ \\
\hline Bagian laba BUMN & $37.133,20$ & $43.904,20$ & $44.695,40$ \\
\hline Penerimaan Bukan Pajak Lainnya & $117.995,40$ & $108.834,60$ & $91.962,10$ \\
\hline Pendapatan Badan Layanan Umum & $41.945,90$ & $47.345,50$ & $43.304,60$ \\
\hline \begin{tabular}{l|l} 
II & Hibah \\
\end{tabular} & $8.987,70$ & $11.629,80$ & $5.383,20$ \\
\hline Jumlah & $1.555 .934,20$ & $1.666 .375,90$ & $1.903 .026,6$ \\
\hline
\end{tabular}

Sumber: Badan Pusat Statistik (2019)

Tabel 2. Pendapatan Asli Daerah Provinsi Lampung Tahun 2016-2018

\begin{tabular}{|c|c|c|c|c|}
\hline No & Realiasi Pendapatan Pemerintah & 2016 & 2017 & 2018 \\
\hline \multirow[t]{5}{*}{1.} & Pendapatan Asli Daerah (PAD) & 2.368.796.251 & 2.750 .582 .686 & 3.179.595.886 \\
\hline & Pajak Daerah & 2.051 .836 .519 & 2.451 .408 .220 & 2.910 .000 .000 \\
\hline & Retribusi Daerah & 7.184 .466 & 7.322 .619 & 7.179 .929 \\
\hline & $\begin{array}{l}\text { Hasil Perusahaan Milik Daerah \& Pengelolaan Kekayaan Daerah yang } \\
\text { Dipisahkan }\end{array}$ & 26.696 .866 & 27.522.159 & 27.559 .514 \\
\hline & Lain-lain PAD yang Sah & 283.078 .400 & 264.329 .688 & 234.856 .443 \\
\hline \multirow[t]{5}{*}{2.} & Dana Perimbangan & 3.158 .712 .900 & 4.028.319.627 & 4.292.543.088 \\
\hline & Bagi Hasil Pajak & 149.737 .823 & 148.414 .293 & 164.068 .277 \\
\hline & Bagi Hasil Bukan Pajak/SDA & 35.738 .174 & 100.925 .750 & 76.170 .544 \\
\hline & Dana Alokasi Umum & 1.321 .679 .032 & 1.851 .595 .354 & 1.857 .043 .487 \\
\hline & Dana Alokasi Khusus & 1.651.557.871 & 1.927 .384 .230 & 2.195 .260 .780 \\
\hline \multirow[t]{2}{*}{3.} & Lain-lain Pendapatan yang Sah & 61.213 .360 & 34.639 .837 & 35.711 .241 \\
\hline & Jumlah & 5.588.722.511 & 6.813.542.150 & 7.507.850.215 \\
\hline
\end{tabular}

Sumber: Badan Pusat Statistik Provinsi Lampung (2019) 
Dari pemaparan data tersebut, pemerintah sudah sepatutnya memaksimalkan pendapatan negara dari sektor pajak, khususnya pajak pelaku Usaha Mikro, Kecil, dan Menengah (UMKM). Sektor UMKM sebagaimana yang kita tahu, memiliki peranan penting dalam mendorong pertumbuhan ekonomi di Indonesia. Saat ini, UMKM telah menjadi agenda utama dalam perekonomian pembangunan yang ada di Indonesia (www.kemenkeu.go.id).

Data dari Kementerian Koperasi dan UKM yang diolah oleh Badan Pusat Statistik (BPS) 2018, jumlah UMKM di Indonesia sebanyak 63,58 juta unit, atau 99\% dari pelaku usaha nasional. UMKM juga memberikan kontribusi terhadap kesempatan kerja sebesar 97,02\%, dan terhadap pembentukan PDB sebesar 60\%. Namun, hanya 1,5 juta yang tercatat sebagai pembayar pajak dengan kontribusi sebesar 2,2\% terhadap total penerimaan pajak penghasilan yang dibayarkan sendiri oleh wajib pajak, adanya ketidakpatuhan tersebut disinyalir karena rumitnya tata cara pengisian dan pelaporan pajak, serta denda yang harus ditanggung oleh wajib pajak apabila menunggak pembayaran pajak dalam hal ini pajak penghasilan (www.katadata.co.id). Selain itu, rendahnya tingkat pengetahuan wajib pajak tentang perpajakan, menjadikan wajib pajak masih belum memahami imbalan nyata yang dirasakan dalam membayar pajak (Burhan, 2015). Hal ini yang menjadi salah satu faktor penyebab wajib pajak enggan memenuhi kewajibannya untuk membayar pajak.

Perlu diketahui bahwa, kepatuhan wajib pajak dapat merupakan perilaku seorang wajib pajak dalam mematuhi seluruh kewajiban perpajakannya serta menggunakan seluruh haknya dengan mengacu pada peraturan perpajakan yang berlaku (Simon \& Clinton, 2010). Heenkenda, (2016) menjelaskan bahwa kepatuhan Wajib Pajak dapat dipengaruhi oleh dua faktor yakni faktor internal dan faktor eksternal. Faktor internal adalah faktor yang berasal dari diri Wajib Pajak sendiri, dan berhubungan dengan karakteristik individu dalam menjalankan kewajiban perpajakannya seperti pengetahuan dan pemahaman tentang peraturan perpajakan. Sedangkan faktor eksternalnya merupakan faktor yang berasal dari luar diri Wajib Pajak contohnya yaitu penerapan $e$ billing.

Dikarenakan pajak masih menjadi prioritas sebagai pemasukan terbesar bagi Indonesia untuk pembangunan negeri, maka perlu dibuat kemudahan dalam menjalankan transaksinya, salah satunya dapat dengan membuat sistem pembayaran pajak secara online atau biasa disebut dengan $e$-billing. Sulistyorini (2017), memaparkan $e$ billing sebagai suatu sistem yang menerbitkan kode billing untuk melakukan proses pembayaran atau penerimaan negara secara elektronik, tanpa perlu membuat Surat Setoran Pajak (SSP) manual. Kelebihan dari e-billing ini sendiri yaitu, sistem pembayaran pajak menjadi lebih mudah, lebih cepat, dan lebih akurat. Dengan adanya penggunaan teknologi tersebut, diharapkan dapat meningkatkan kepatuhan Wajib Pajak pelaku usaha mikro, kecil, dan menengah dalam hal membayar pajak, karena akan memudahkan Wajib Pajak dalam melakukan pembayaran pajak. (Fadilah, 2018).

Faktor lainnya yang disinyalir mempengaruhi kepatuhan wajib pajak dalam memenuhi kewajiban perpajakannya adalah pemahaman tentang perpajakan, seperti undang-undang perpajakan, tata cara pembayaran pajak, maupun peraturan terbaru pemerintah No. 23 tahun 2018 tentang pengurangan biaya PPh Final bagi pelaku usaha mikro, kecil, dan menengah menjadi hanya $0,5 \%$ yang sebelumnya sebesar $1 \%$. Apabila wajib pajak tidak memiliki pengetahuan perpajakan, maka wajib pajak akan mengalami 
kesulitan dalam mendaftarkan diri, dan menyetorkan pajaknya. Untuk itu pemerintah membuat peraturan baru terkait perpajakan yang mana tujuan dari pemberlakuan Peraturan Pemerintah ini adalah untuk memudahkan masyarakat dalam melaksanakan kewajiban perpajakannya, mulai dari melakukan perhitungan, penyetoran dan pelaporan pajak, serta meningkatkan pengetahuan tentang manfaat perpajakan bagi masyarakat dan pelaku UMKM khususnya, yang nantinya akan membuat wajib pajak menjadi patuh dalam memenuhi kewajiban perpajakannya (Marista dan Fajriana, 2014).

Waluyo (2011), mendefinisikan pemahaman perpajakan sebagai suatu proses dimana wajib wajak mengetahui dan memahami tentang perpajakan mulai dari undang-undang sampai pada tata cara perpajakan yang benar dan mengaplikasikannya untuk membayar pajak. Wajib pajak yang memiliki pengetahuan tentang pajak yang baik akan dapat memperkecil adanya penggelapan pajak atau tax evasion (Witono, 2008).

Berdasarkan uraian yang telah dijabarkan pada latar belakang, maka hipotesis dalam penelitian ini adalah sebagai berikut:

H1 : E-billing berpengaruh signifikan terhadap kepatuhan pajak

H2 : Pemahaman perpajakan berpengaruh signifikan terhadap kepatuhan pajak

H3 : E-billing dan Pemahaman perpajakan berpengaruh signifikan terhadap kepatuhan pajak

\section{METODE PENELITIAN}

Penelitian ini merupakan jenis penelitian explanatory research dengan pendekatan kuantitatif. Populasi dalam penelitian ini adalah Wajib Pajak pelaku UMKM yang terdaftar di KPP Pratama Tanjung Karang. Sampel dalam penelitian ini sebanyak 100 responden, yang didapat dengan mengunakan rumus Slovin dengan tingkat toleransi kesalahan (margin of eror) sebesar 10\%. Penarikan sampel dalam penelitian ini menggunakan non probability sampling dengan teknik sampling yang digunakan yaitu purposive sampling, teknik pengambilan sampel dengan didasarkan ciri- ciri khusus yang sesuai dengan tujuan penelitian sehingga diharapkan dapat menjawab permasalahan penelitian (Sugiyono 2017).

\section{HASIL PENELITIAN}

\section{Analisis Statistik Deskriptif}

Karakteristik Responden

1. Karakteristik Responden Berdasarkan Kepemilikan NPWP

Berdasarkan kepemilikan NPWP menunjukkan bahwa 100\% responden menjawab "Iya", semua responden memiliki nomor pokok wajib pajak (NPWP).

\section{Karakteristik Responden Berdasarkan Pengalaman Pernah Menggunakan E-billing}

Pada Gambar 1. dapat dilihat bahwa terdapat persentase sebesar $71 \%$ responden pernah menggunakan e-billing, dan hanya sebesar $29 \%$ dari responden yang belum pernah menggunakan e-billing. Hal tersebut menunjukkan bahwa sosialisasi yang 
dilakukan oleh petugas pajak dalam hal ini Direktorat Jenderal Pajak terkait penggunaan e-billing atau sistem pembayaran pajak secara online sudah dilaksanakan dengan baik.

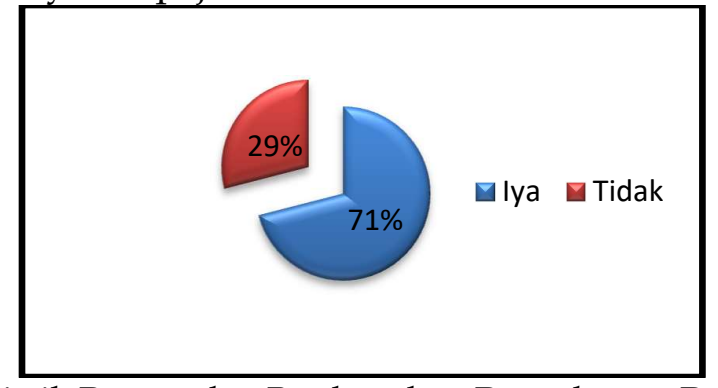

Gambar 1. Karakteristik Responden Berdasarkan Pengalaman Pernah Menggunakan E-billing

\section{Karakteristik Responden Berdasarkan Jenis Kelamin}

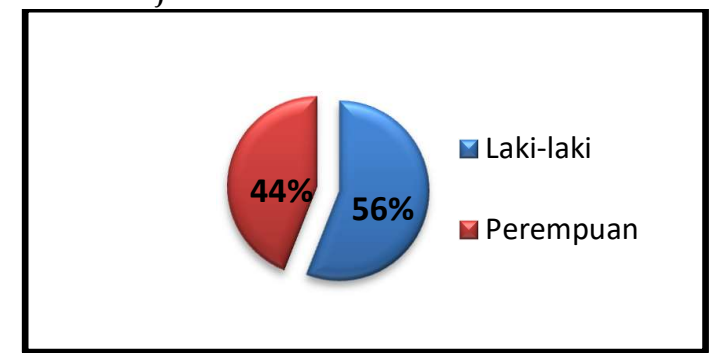

Gambar 2. Karakteristik Responden Berdasarkan jenis kelamin

Pada Gambar 2. dapat dilihat bahwa persentase responden dalam penelitian ini terdiri dari responden laki-laki sebesar $56 \%$ dan responden perempuan sebesar $44 \%$. Hal ini menunjukkan bahwa karakteristik responden berdasarkan jenis kelamin menyebar rata antara laki-laki dan perempuan karena tidak terjadi perbedaan yang jauh atau tidak ada dominasi.

\section{Karakteristik Reponden Berdasarkan Usia}

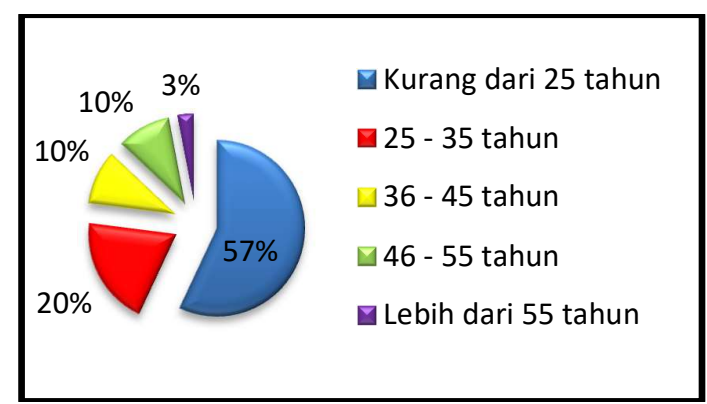

Gambar 3. Karakteristik Responden Berdasarkan Usia

Ilustrasi Gambar 3. Memperlihatkan bahwa sebesar 57\% responden adalah pelaku usaha dengan usia kurang dari 25 tahun dan merupakan jumlah responden terbanyak, diikuti pelaku usaha dengan rentang usia 25-35 tahun sebesar 20\%, lalu persentase usia pelaku usaha yang sama yaitu sebesar $10 \%$ pada rentang 36-45 tahun dan 46-55 tahun, dan yang terakhir pelaku usaha dengan usia diatas 55 tahun sebesar 3\%. Dalam penelitian ini dapat diketahui bahwa mayoritas responden sebagian besar adalah pengusaha muda dengan rentang usia masih di bawah 25 tahun.

\section{Karakteristik Responden Berdasarkan Pendidikan Terakhir}




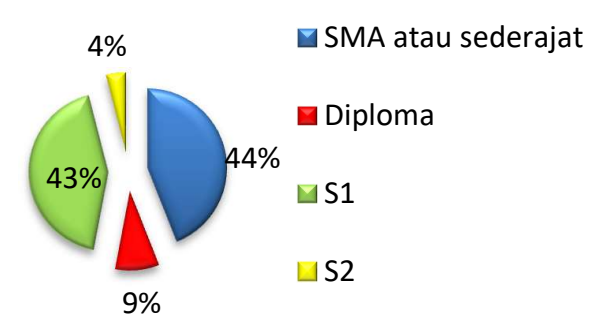

Gambar 1.5 Karakteristik Responaen Berdasarkan Pendidikan Terakhir

Berdasarkan Gambar 1.5 dapat diketahui bahwa persentase sebesar 44\% responden adalah berpendikan akhir SMA atau sederajat, diikuti S1 dengan persentase yang tidak terpaut jauh yaitu sebesar $43 \%$, diploma sebesar 9\% dan yang terrakhit adalah S2 sebesar $4 \%$.

\subsection{Karakteristik Responden Berdasarkan Lama Berdirinya Usaha}

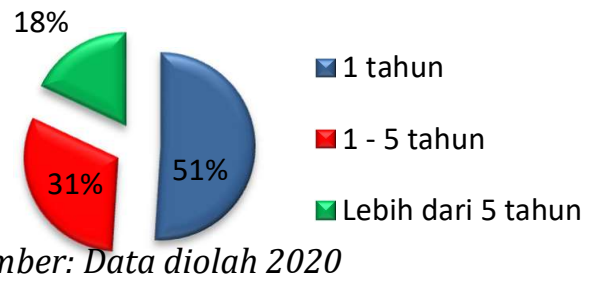

Sumber: Data diolah 2020

Gambar 1.6 Karakteristik Responden Betdasarkan Lama Berdirinya Usaha

Berdasarkan Gambar 1.6 dapat dilihat bahwa lama berdirinya usaha paling banyak baru berjalan selama 1 tahun dengan persentase sebesar 51\%. Kemudian sebesar 31\% responden sudah menjalankan usahanya selama 1 - 5 tahun, dan 18\% responden telah menjalankan usahanya lebih dari 5 tahun.

\subsection{Karakteristik Responden Berdasarkan Omzet Per Tahun}

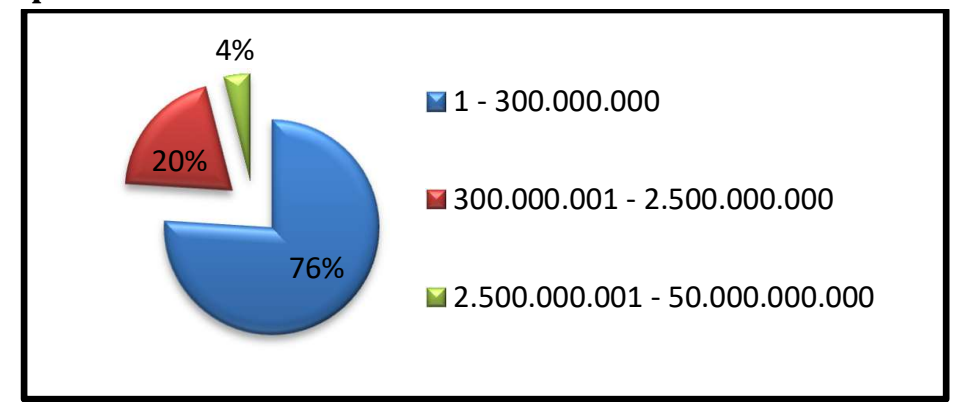

Gambar 1.7 Karakteristik Responden Berdasarkan Lama Berdirinya Usaha

Berdasarkan Gambar 1.7 dapat dilihat bahwa responden pelaku usaha pada skala mikro merupakan responden terbanyak dengan jumlah persentase sebesar $76 \%$ dan omzet per tahun dibawah hingga sampai Rp.300.000.000, diikuti responden pelaku usaha pada skala kecil dengan persentase $20 \%$ dan omzet per tahun sebesar Rp.300.000.001 Rp.2.500.000.000, serta yang terakhir responden pelaku usaha pada skala menengah dengan persentase sebesar $4 \%$ dan omzet per tahunnya berkisar antara Rp.2.500.000.001 Rp. 50.000.000.000. 
Distribusi Jawaban Responden

1. E-billing

Analisis deskriptif jawaban responden tentang variabel e-billing didasarkan pada item pertanyaan-pertanyaan seperti yang terdapat dalam kuesioner yang disebarkan kepada responden. Berikut ini adalah jawaban responden penelitian ini terkait dengan indikator e-billing pada Wajib Pajak pelaku UMKM yang terdaftar di KPP Pratama Tanjung Karang:

Tabel 3. Distribusi Frekuensi Penilaian Responden pada Variabel E-billing

\begin{tabular}{|l|l|l|l|l|l|l|}
\hline E-billing (X1) & STS & TS & N & S & SS & Total \\
\hline Item & 3 & 8 & 32 & 37 & 20 & 100 \\
\hline X1.1 & $3,00 \%$ & $8,00 \%$ & $32,00 \%$ & $37,00 \%$ & $20,00 \%$ & $100 \%$ \\
\hline & 1 & 3 & 19 & 37 & 40 & 100 \\
\hline X1.2 & $1,00 \%$ & $3,00 \%$ & $19,00 \%$ & $37,00 \%$ & $40,00 \%$ & $100 \%$ \\
\hline & 1 & 1 & 17 & 42 & 39 & 100 \\
\hline X1.3 & $1,00 \%$ & $1,00 \%$ & $17,00 \%$ & $42,00 \%$ & $39,00 \%$ & $100 \%$ \\
\hline & 1 & 9 & 25 & 31 & 34 & 100 \\
\hline X1.4 & $1,00 \%$ & $9,00 \%$ & $25,00 \%$ & $31,00 \%$ & $34,00 \%$ & $100 \%$ \\
\hline & 0 & 2 & 22 & 40 & 36 & 100 \\
\hline X1.5 & $0,00 \%$ & $2,00 \%$ & $22,00 \%$ & $40,00 \%$ & $36,00 \%$ & $100 \%$ \\
\hline & 0 & 5 & 18 & 48 & 29 & 100 \\
\hline X1.6 & $0,00 \%$ & $5,00 \%$ & $18,00 \%$ & $48,00 \%$ & $29,00 \%$ & $100 \%$ \\
\hline & 1 & 1 & 23 & 45 & 30 & 100 \\
\hline X1.7 & $1,00 \%$ & $1,00 \%$ & $23,00 \%$ & $45,00 \%$ & $30,00 \%$ & $100 \%$ \\
\hline & 1 & 3 & 14 & 50 & 32 & 100 \\
\hline X1.8 & $1,00 \%$ & $3,00 \%$ & $14,00 \%$ & $50,00 \%$ & $32,00 \%$ & $100 \%$ \\
\hline & 8 & 32 & 170 & 330 & 260 & 800 \\
\hline Total & $1,00 \%$ & $4,00 \%$ & $21,25 \%$ & $41,25 \%$ & $32,50 \%$ & $100 \%$ \\
\hline & $5 \%$ & & $21,25 \%$ & $73,75 \%$ & & $100 \%$ \\
\hline Persentase Positif Negatif & 5 & & & & \\
\hline
\end{tabular}

Berdasarkan tabel 3., menunjukkan bahwasanya responden yang menjawab positif (setuju \& sangat setuju) sejumlah 73,75\%, lalu sebesar 5\% menjawab negatif (tidak setuju \& sangat tidak setuju), serta 21,25\% menjawab netral. Pada variabel e-billing, item tertinggi dengan responden memberikan penilaian positif sebesar $82,00 \%$ terletak pada item no.8 dengan pernyataan "Dengan diterapkannya sistem e-billing, kesalahan input data yang biasa terjadi di teller dapat terminimalisasi karena data yang akan muncul pada layar adalah data yang telah saya input sendiri sesuai dengan transaksi perpajakan yang benar.", hal ini menunjukkan bahwa salah satu manfaat yang di dapat dari penggunaan e-billing adalah dapat meminimalisir terjadinya kesalahan input data karena pengisian data dapat dilakukan sendiri oleh Wajib Pajak.

\section{Pemahaman Perpajakan}

Analisis deskriptif jawaban responden tentang variabel pemahaman perpajakan didasarkan pada item pertanyaan-pertanyaan seperti yang terdapat dalam kuesioner yang disebarkan kepada responden. Berikut ini adalah jawaban responden penelitian ini terkait dengan indikator pemahaman perpajakan pada Wajib Pajak pelaku UMKM yang terdaftar di KPP Pratama Tanjung Karang: 
Tabel 4. Distribusi Frekuensi Penilaian Responden pada Variabel Pemahaman Perpajakan

\begin{tabular}{|l|l|l|l|l|l|l|}
\hline Pemahaman Perpajakan (X2) & \multicolumn{5}{|l|}{} \\
\hline Item & STS & TS & N & S & SS & Total \\
\hline X2.1 & 3 & 9 & 28 & 38 & 22 & 100 \\
\hline & $3,00 \%$ & $9,00 \%$ & $28,00 \%$ & $38,00 \%$ & $22,00 \%$ & $100 \%$ \\
\hline X2.2 & 2 & 11 & 26 & 40 & 21 & 100 \\
\hline & $2,00 \%$ & $11,00 \%$ & $26,00 \%$ & $40,00 \%$ & $21,00 \%$ & $100 \%$ \\
\hline X2.3 & 2 & 7 & 24 & 46 & 21 & 100 \\
\hline & $2,00 \%$ & $7,00 \%$ & $24,00 \%$ & $46,00 \%$ & $21,00 \%$ & $100 \%$ \\
\hline X2.4 & 1 & 7 & 28 & 39 & 25 & 100 \\
\hline & $1,00 \%$ & $7,00 \%$ & $28,00 \%$ & $39,00 \%$ & $25,00 \%$ & $100 \%$ \\
\hline X2.5 & 0 & 2 & 27 & 46 & 25 & 100 \\
\hline & $0,00 \%$ & $2,00 \%$ & $27,00 \%$ & $46,00 \%$ & $25,00 \%$ & $100 \%$ \\
\hline X2.6 & 3 & 11 & 38 & 31 & 17 & 100 \\
\hline & $3,00 \%$ & $11,00 \%$ & $38,00 \%$ & $31,00 \%$ & $17,00 \%$ & $100 \%$ \\
\hline X2.7 & 2 & 5 & 24 & 41 & 28 & 100 \\
\hline & $2,00 \%$ & $5,00 \%$ & $24,00 \%$ & $41,00 \%$ & $28,00 \%$ & $100 \%$ \\
\hline X2.8 & 3 & 3 & 24 & 46 & 24 & 100 \\
\hline & $3,00 \%$ & $3,00 \%$ & $24,00 \%$ & $46,00 \%$ & $24,00 \%$ & $100 \%$ \\
\hline Total & 16 & 55 & 219 & 327 & 183 & 800 \\
\hline & $2,00 \%$ & $6,87 \%$ & $27,37 \%$ & $40,88 \%$ & $22,88 \%$ & $100 \%$ \\
\hline Persentase Positif Negatif & $8,87 \%$ & & $27,37 \%$ & $63,76 \%$ & & $100 \%$ \\
\hline
\end{tabular}

Berdasarkan distribusi jawaban responden mengenai variabel pemahaman perpajakan (X2) pada tabel 2.2, responden yang menjawab positif (setuju \& sangat setuju) sejumlah 63,74\%, lalu sebesar 8,87\% menjawab negatif (tidak setuju \& sangat tidak setuju), serta 27,37\% menjawab netral. Pada variabel pemahaman perpajakan, item tertinggi dengan responden memberikan penilaian positif sebesar $71,00 \%$ terletak pada item no.5 dengan pernyataan "Saya memahami pajak yang berlaku bagi usaha yang saya jalankan", hal ini menunjukkan bahwa para Wajib Pajak sudah memahami pajak yang berlaku bagi usaha mereka sesuai dengan ketentuan perundang-undangan yang berlaku, mulai dari jenis pajak yaitu PPh final, sampai biaya pajak yang dikenakan kepada mereka.

\section{Kepatuhan Pajak}

Analisis deskriptif jawaban responden tentang kepatuhan pajak didasarkan atas pertanyaan-pertanyaan seperti yang terdapat dalam kuisioner yang disebarkan pada responden. Berikut jawaban responden penelitian ini terkait dengan indikator kepatuhan pajak pada Wajib Pajak pelaku UMKM yang terdaftar di KPP Pratama Tanjung Karang:

Tabel 5. Distribusi Frekuensi Penilaian Responden pada Variabel Kepatuhan Pajak

\begin{tabular}{|c|c|c|c|c|c|c|}
\hline \multicolumn{7}{|c|}{ Kepatuhan Pajak (Y) } \\
\hline Item & STS & TS & $\mathrm{N}$ & S & SS & Total \\
\hline \multirow[t]{2}{*}{ Y1 } & 0 & 5 & 14 & 49 & 32 & 100 \\
\hline & $0,00 \%$ & $5,00 \%$ & $14,00 \%$ & $49,00 \%$ & $32,00 \%$ & $100 \%$ \\
\hline \multirow[t]{2}{*}{ Y2 } & 0 & 4 & 17 & 49 & 30 & 100 \\
\hline & $0,00 \%$ & $4,00 \%$ & $17,00 \%$ & $49,00 \%$ & $3,00 \%$ & $100 \%$ \\
\hline \multirow[t]{2}{*}{ Y3 } & 0 & 5 & 30 & 39 & 26 & 100 \\
\hline & $0,00 \%$ & $5,00 \%$ & $30,00 \%$ & $39,00 \%$ & $26,00 \%$ & $100 \%$ \\
\hline \multirow[t]{2}{*}{ Y4 } & 0 & 8 & 26 & 45 & 21 & 100 \\
\hline & $0,00 \%$ & $8,00 \%$ & $26,00 \%$ & $45,00 \%$ & $21,00 \%$ & $100 \%$ \\
\hline
\end{tabular}




\begin{tabular}{|l|l|l|l|l|l|l|}
\hline Y5 & 1 & 2 & 23 & 55 & 19 & 100 \\
\hline & $1,00 \%$ & $2,00 \%$ & $23,00 \%$ & $55,00 \%$ & $19,00 \%$ & $100 \%$ \\
\hline Y6 & 1 & 4 & 21 & 44 & 30 & 100 \\
\hline & $1,00 \%$ & $4,00 \%$ & $21,00 \%$ & $44,00 \%$ & $30,00 \%$ & $100 \%$ \\
\hline Total & 2 & 28 & 131 & 281 & 158 & 600 \\
\hline & $0,33 \%$ & $4,67 \%$ & $21,83 \%$ & $46,83 \%$ & $26,33 \%$ & $100 \%$ \\
\hline Persentase Positif Negatif & $5 \%$ & & $21,83 \%$ & $73,16 \%$ & & $100 \%$ \\
\hline
\end{tabular}

Berdasarkan distribusi jawaban responden variabel kepatuhan pajak (Y) pada tabel 2.3, menunjukkan bahwasanya responden yang menjawab positif (setuju \& sangat setuju) sejumlah 73,16\%, lalu sebesar 5\% menjawab negatif (tidak setuju \& sangat tidak setuju), serta $21,83 \%$ menjawab netral. Pada variabel kepatuhan pajak, item tertinggi dengan responden memberikan penilaian positif sebesar $81,00 \%$ terletak pada item no.1 dengan pernyataan "Saya mendaftarkan Nomor Pokok Wajib Pajak (NPWP) atas kemauan sendiri", hal ini menunjukkan bahwa para Wajib Pajak sudah memiliki kesadaran dari mereka sendiri selaku warga negara yang harus taat pajak, sehingga mau mendaftarkan diri mereka ke kantor pajak.

\section{Teknik Pengujian Instrumen}

\section{Uji Validitas}

Pengujian validitas pada penelitian ini dihitung dengan menggunakan bantuan program SPSS 25.0 dengan cara menguji setiap item pertanyaan dari masing-masing variabel. Penelitian ini di lakukan pre-test sebanyak 30 responden dengan nilai $r$ tabel sebesar 0,349. Suatu intrument dikatakan valid apabila nilai rhitung > rtabel.

\section{Uji Reliabilitas}

Uji reliabel pada penelitian ini menggunakan SPSS (Stastical Package for Social Science software) 25, variabel dapat diukur secara bersama-sama terhadap seluruh butir pertanyaan. Jika nilai alpha $>0,6$ maka reliabel, dan sebaliknya apabila nilai alpha $<0,6$ maka tidak reliabel.

Uji Regresi Linier Berganda

Tabel 6. Uji Regresi Linier Berganda

\begin{tabular}{|c|c|c|c|c|}
\hline \multicolumn{5}{|c|}{ Coefficients $^{a}$} \\
\hline \multirow{2}{*}{\multicolumn{2}{|c|}{ Model }} & \multicolumn{2}{|c|}{ Unstandardized Coefficients } & \multirow{2}{*}{$\begin{array}{l}\text { Standardized Coefficients } \\
\text { Beta }\end{array}$} \\
\hline & & $\mathrm{B}$ & Std. Error & \\
\hline \multirow[t]{3}{*}{1} & (Constant) & 9.146 & 1.811 & \\
\hline & E-billing & .146 & .070 & .212 \\
\hline & Pemahaman Perpajakan & .327 & .068 & .491 \\
\hline
\end{tabular}

Berdasarkan tabel 6. menunjukkan bahwa nilai coefficient konstanta sebesar 9,146, nilai e-billing, sebesar 0,146, nilai pemahaman perpajakan sebesar 0,327. Berdasarkan nilainilai tersebut maka persamaan regresinya adalah sebagai berikut: 


$$
\begin{aligned}
& \mathrm{Y}=\mathrm{a}+\beta 1 X 1+\beta 2 X 2+\mathrm{e} \\
& \mathrm{Y}=9,146+0,146+0,327
\end{aligned}
$$

Persamaan regresi di atas dapat dijelaskan sebagai berikut:

1. Persamaan regresi linear berganda dapat dijelaskan bahwa persamaan regresi mempunyai nilai konstanta sebesar 9,146 yang berarti jika e-billing dan pemahaman perpajakan nilainya adalah 0 , maka besarnya kepatuhan pajak adalah sebesar 9,146.

2. Koefisien regresi linear berganda variabel e-billing sebesar 0,146. Berarti setiap terjadi kenaikan nilai 1 dari variabel e-billing, maka kepatuhan pajak akan mengalami kenaikan sebesar 0,146. Koefisien regresi bernilai positif (+) yang artinya terjadi pengaruh positif antara variabel e-billing terhadap kepatuhan pajak.

3. Koefisien regresi linear berganda variabel pemahaman perpajakan sebesar 0,327. Berarti setiap terjadi kenaikan nilai 1 dari variabel pemahaman perpajakan maka kepatuhan pajak akan mengalami kenaikan sebesar 0,327. Koefisien regresi bernilai positif (+) yang artinya terjadi pengaruh positif antara variabel pemahaman perpajakan terhadap kepatuhan pajak.

\section{Uji Hipotesis}

Uji $t$

Tabel 7. Hasil Uji t

\begin{tabular}{|l|l|l|l|}
\hline Model & Standardized Coefficients & $\mathrm{t}$ & Sig. \\
\hline (Constant) & Beta & 5.049 & .000 \\
\hline E-billing & .212 & 2.079 & .040 \\
\hline Pemahaman Perpajakan & .491 & 4.811 & .000 \\
\hline
\end{tabular}

Berdasarkan tabel 7. dapat dilihat bahwa t hitung variabel e-billing sebesar 2.079 dengan signifikansi probabilitas sebesar 0,040, variabel pemahaman perpajakan memiliki nilai t hitung sebesar 4.811 dengan signifikansi probabilitas sebesar 0,000. Berdasarkan nilai-nilai tersebut maka dapat disimpulkan bahwa:

a) Hasil Pengujian E-billing

Dapat diinterpretasikan $t_{\text {hitung }}>t_{\text {tabel, }}$ yaitu $2.079>1,660$ dan nilai signifikansi $0,040<$ 0,05. Maka Ha diterima berarti secara parsial dapat disimpulkan bahwa e-billing berpengaruh signifikan terhadap kepatuhan pajak sebesar $21,2 \%$.

b) Hasil Pengujian Pemahaman Perpajakan

Dapat diinterpretasikan $t_{\text {hitung }}>\mathrm{t}_{\text {tabel, }}$ yaitu $4.811>1,660$ dan nilai signifikansi $0,000<$ 0,05. Maka Ha diterima berarti secara parsial dapat disimpulkan bahwa pemahaman perpajakan berpengaruh signifikan terhadap kepatuhan pajak sebesar 49,1\%.

Uji F

Tabel 8. Hasil Uji F

\begin{tabular}{|l|l|r|r|r|l|l|}
\hline \multicolumn{7}{|l|}{ ANOVAa } \\
\hline Model & Sum of Squares & df & \multicolumn{1}{l|}{ Mean Square } & F & Sig. \\
\hline \multirow{3}{*}{1} & Regression & 524.508 & 2 & 262.254 & 35.517 & $.000^{\mathrm{b}}$ \\
\cline { 2 - 7 } & Residual & 716.242 & 97 & 7.384 & & \\
\cline { 2 - 7 } & Total & 1240.750 & 99 & & & \\
\hline
\end{tabular}


Tabel 8. menunjukkan bahwa nilai $f_{\text {hitung }}$ sebesar 35,517 dengan tingkat signifikasi 0,000. Pada tabel tersebut terlihat $\mathrm{df}_{1}=\mathrm{k}=1=3-1=2$ dengan $\mathrm{df}_{2}=\mathrm{n}-\mathrm{k}=100-3=97$ dengan derajat kebebasan 0,05 diperoleh $\mathrm{F}_{\text {tabel }}$ 3,09. Berdasarkan data tersebut menunjukkan bahwa $f_{\text {hitung }}>\mathrm{f}_{\text {tabel }}(35,517>3,09)$ probabilitas $0,000<0,05$, Dari hasil tersebut membuktikan bahwa Ha diterima, artinya ada pengaruh signifikan antara e-billing dan pemahaman perpajakan secara bersama-sama terhadap kepatuhan pajak.

Uji $R^{2}$

Tabel 9. Hasil Uji R²

\begin{tabular}{|l|r|r|r|l|r|}
\hline Model Summary & & & \multicolumn{2}{l|}{$\begin{array}{l}\text { Std. Error of the } \\
\text { Estimate }\end{array}$} & Durbin-Watson \\
\hline Model & $\mathrm{R}$ & R Square & Adjusted R Square & 2.717 & \\
\hline 1 & $.650^{\mathrm{a}}$ & .423 & .411 & \\
\hline
\end{tabular}

Pada tabel 9. dapat dilihat bahwa dalam penelitian ini menunjukkan angka $\mathrm{R}$ sebesar 0,650, pada pedoman interpretasi angka ini menunjukkan bahwa korelasi atau hubungan antara kepatuhan pajak dengan variabel e-billing, dan pemahaman perpajakan adalah kuat. Nilai koefisien determinasi (R2) yang ditunjukan oleh R-square sebesar 0,423. Angka tersebut menunjukan besar pengaruh variabel independen yang terdiri dari e-billing dan pemahaman perpajakan sebesar 0,423 atau 42,3\%. Hal tersebut dapat diartikan bahwa sebesar $42,3 \%$ variabel kepatuhan pajak dipengaruhi oleh dua variabel independen dalam penelitian ini yakni e-billing dan pemahaman perpajakan, serta sisanya dipengaruhi oleh variabel-variabel lain yang tidak diteliti dalam penelitian ini.

\section{PEMBAHASAN}

\section{Pengaruh E-billing Terhadap Kepatuhan Pajak}

Berdasarkan hasil perhitungan uji hipotesis secara parsial atau uji t pada variabel $e$ billing, menunjukkan bahwa $t_{\text {hitung }}>\mathrm{t}_{\text {tabel }}$ yaitu $2.079>1,660$ dan nilai signifikansi 0,040< 0,05 sehingga secara parsial dapat diartikan variabel e-billing (X1) berpengaruh signifikan terhadap kepatuhan pajak (Y).

Data tersebut didukung oleh beberapa alasan yang dapat dilihat pada hasil distribusi tanggapan responden, dengan item tertinggi dari jawaban responden memberikan penilaian positif (setuju dan sangat setuju) sebagai contoh pernyataannya yakni "Dengan diterapkannya sistem e-billing, kesalahan input data yang biasa terjadi di teller dapat terminimalisasi karena data yang akan muncul pada layar adalah data yang telah saya input sendiri sesuai dengan transaksi perpajakan yang benar.", dan "Dengan diterapkannya sistem $e$-billing, saya tidak perlu lagi membawa lembaran SSP ke Bank atau Kantor Pos Persepsi". Hal ini dikarenakan ada kelebihan yang didapat ketika menggunakan aplikasi $e$-billing diantaranya yaitu lebih mempermudah dan mempercepat pembayaran pajak karena Wajib Pajak hanya cukup mengisi SSP elektronik melalui $e$ billing lalu melakukan pembayaran, dan dapat meminimalisir terjadinya kesalahan input data, karena pengisian data dapat dilakukan sendiri oleh Wajib Pajak. 
Hasil penelitian ini sejalan dengan teori Technology Acceptance Model (TAM) yang dikemukakan oleh Davis (1989), dalam Fatmawati (2015), yang menjelaskan bahwa TAM merupakan suatu model untuk memprediksi dan menjelaskan bagaimana pengguna tekonologi menerima dan menggunakan teknologi dalam pekerjaan individual pengguna. TAM bekerja berdasarkan dua indikator yaitu persepsi kegunaan (perceived usefulness) dan persepsi kemudahan penggunaan (perceived ease of use) yang dapat memprediksi penerimaan pengguna terhadap teknologi. Manfaat yang dapat dirasakan dan selaras dengan kepentingan wajib pajak akan memotivasi wajib pajak untuk memilih berperilaku patuh dalam melaksanakan kewajiban perpajakan.

e-billing yang dikeluarkan oleh Direktorat Jenderal Pajak memberikan kemudahan untuk Wajib Pajak dalam pelaporan dan pembayaran kewajiban pajaknya karena dapat menghemat waktu. Berdasarkan hal tersebut menjadikan wajib pajak semakin patuh dalam pembayaran pajaknya.

Penelitian ini juga sesuai dengan penelitian yang dilakukan oleh Anisa Febriana, (2019) yang menunjukkan bahwa e-billing berpengaruh positif terhadap kepatuhan pajak. Ketika wajib pajak telah merasakan manfaat yang didapat dari e-billing, maka akan memudahkan mereka dalam melakukan proses pelaporan dan pembayaran pajak, sehingga membuat wajib pajak menjadi patuh dalam melaksanakan kewajiban perpajakannya.

\section{Pengaruh Pemahaman Perpajakan Terhadap Kepatuhan Pajak}

Berdasarkan hasil perhitungan uji hipotesis secara parsial atau uji $\mathrm{t}$ pada variabel pemahaman perpajakan menunjukkan bahwa $t_{\text {hitung }}>t_{\text {tabel }}$ yaitu $4.811>1,660$ dan nilai signifikansi $0,000<0,05$ sehingga secara parsial dapat diartikan variabel pemahaman perpajakan (X2) berpengaruh signifikan terhadap kepatuhan pajak (Y).

Data tersebut didukung oleh alasan yang dapat dilihat pada hasil distribusi tanggapan responden, dengan item tertinggi dari jawaban responden memberikan penilaian positif (setuju dan sangat setuju) sebagai contoh pernyataannya yakni "Saya memahami pajak yang berlaku bagi usaha yang saya jalankan", hal ini dikarenakan para wajib pajak sudah memahami pajak yang berlaku bagi usaha mereka sesuai dengan ketentuan perundang-undangan yang berlaku, mulai dari jenis pajak yaitu PPh final, sampai biaya pajak yang dikenakan kepada mereka.

Penelitian ini sejalan dengan teori atribusi yang dijelaskan oleh Robbins, (2008) bahwa apabila individu-individu mengamati perilaku seseorang, mereka mencoba untuk menentukan apakah itu ditimbukan secara internal atau eksternal. Perilaku yang disebabkan dari dalam diri individu itu sendiri atau berasal dari faktor internal seperti ciri kepribadian, kesadaran, dan kemampuan, disebut dengan atribusi internal. Masruroh, (2013) menjelaskan bahwa pemahaman wajib pajak tentang peraturan perpajakan merupakan penyebab internal karena berada di bawah kendali wajib pajak sendiri.

Pemahaman wajib pajak khususnya para pelaku UMKM saat ini, tentang peraturan perpajakan sudah terbilang baik, karena mereka sadar akan pentingnya pajak dan fungsi dari pajak itu sendiri, sehingga wajib pajak mau untuk membayarkan pajaknya. Walaupun begitu, peningkatan pemahaman wajib pajak tentang peraturan perpajakan harus terus dilakukan oleh pihak-pihak terkait, baik wajib pajak maupun aparat pajak, sehingga kepatuhan pajak dapat semakin meningkat. 
Hasil penelitian ini sejalan dengan penelitian yang dilakukan oleh Elvania Nur Fadzilah, dkk (2017) yang mengemukakan bahwa pemahaman perpajakan berpengaruh positif dan signifikan terhadap kepatuhan pajak. Dengan tingkat pemahaman wajib pajak yang tinggi akan membuat wajib pajak memilih berperilaku patuh dalam melaksanakan kewajiban perpajakan.

\section{Pengaruh E-billing dan Pemahaman Perpajakan Terhadap Kepatuhan Pajak}

Berdasarkan hasil uji hipotesis simultan menggunakan uji F, diperoleh bahwa " $e$ billing, dan pemahaman perpajakan berpengaruh secara simultan terhadap kepatuhan pajak". Hasil ini dapat diketahui dengan melihat nilai $\mathrm{F}$ signifikan sebesar 0,05 dan nilai $\mathrm{f}_{\text {hitung }}>\mathrm{f}_{\text {tabel }}$ yaitu $\mathrm{f}_{\text {hitung }}>\mathrm{f}_{\text {tabel }}(35,517>3,09)$ dengan probabilitas $0,000<0,05$, jadi dapat diketahui bahwa variabel e-billing, dan pemahaman perpajakan berpengaruh secara simultan atau bersama-sama terhadap kepatuhan pajak.

Pada hasil uji R2 menunjukkan bahwa pada angka $\mathrm{R}$ sebesar 0,650 pada pedoman interpretasi angka ini menunjukkan bahwa korelasi atau hubungan antara kepatuhan pajak dengan kedua variabel independen (e-billing dan pemahaman perpajakan) adalah kuat dan positif. Pada penelitian ini nilai koefisien R2 dengan melihat nilai $\mathrm{R}$ Square sebesar 0,423 atau 42,3\%. Hal ini menunjukkan bahwa adanya kontribusi variabel independen (e-billing dan pemahaman perpajakan) yakni sebesar 42,3\%. Hal tersebut menggambarkan presentase pengaruh variabel e-billing dan pemahaman perpajakan terhadap kepatuhan pajak adalah sedang, dan sisanya dijelaskan oleh faktor lain yang tidak diteliti pada penelitian ini.

\section{KESIMPULAN}

E-billing pada penelitian ini berpengaruh positif dan signifikan secara parsial terhadap kepatuhan pajak pelaku UMKM yang terdaftar di KPP Pratama Tanjung Karang dengan persentase sebesar $21,2 \%$. Berdasarkan respon tertinggi yang berikan konsumen terletak pada aspek keamanan dan kemudahan dari sistem e-billing, hal ini berarti bahwa wajib pajak menerima sistem perpajakan online tersebut dan membuat wajib pajak menjadi patuh.

Pemahaman perpajakan pada penelitian ini berpengaruh positif dan signifikan secara parsial terhadap kepatuhan pajak pelaku UMKM yang terdaftar di KPP Pratama Tanjung Karang sebesar 49,1\%. Berdasarkan respon tertinggi yang diberikan konsumen terletak pada aspek pemahaman akan pajak dari usaha yang mereka jalankan, hal ini berarti bahwa wajib pajak telah memahami tentang pentingnya pajak dan manfaat dari pajak itu sendiri sehingga membuat mereka menjadi patuh dalam menjalankan kewajiban pajaknya.

Secara simultan e-billing, dan pemahaman perpajakan berpengaruh positif dan signifikan terhadap kepatuhan pajak pelaku UMKM yang terdaftar di KPP Pratama Tanjung Karang.

\section{DAFTAR PUSTAKA}

Badan Pusat Statistik. 2019. https://www.bps.go.id/statictable/2014/09/12/1179/anggaran-pendapatan- 
negara-miliar-rupiah-2016-2018. Diakses pada 02 Desember 2019 pukul 09.58.

Badan Pusat Statistik Provinsi Lampung. 2019. https:/ / bulelengkab.go.id/assets/instansikab/ 126/bankdata/statistik-keuangan-pemerintah-propinsi-2015-2018-17.pdf. Diakses pada 29 Januari 2020 pukul 10.10 .

Burhan, H.W. 2015. Pengaruh sosialisasi perpajakan, pengetahuan perpajakan, persepsi wajib pajak tentang sanksi pajak dan implementasi pp nomor 46 tahun 2013 terhadap kepatuhan wajib pajak orang pribadi di Kabupaten Banjarnegara. Jurnal Fakultas Ekonomika dan Bisnis Universitas Diponegoro Semarang

Davis, FD. 1989. "Technology Acceptance Model For Empirically Testing New End-User Information System Theory And Result." Dissertation. Massachusetts Institute of Technology (MIT)

Fadilah, Isyarah. 2018. Pengaruh Penerapan E-registration, E-filling, dan E-billing terhadap Tingkat Kepuasan dan Dampaknya pada Kepatuhan Wajib Pajak.

Fadzilah, Elvania Nur., Rasyid Mei Mustafa., dan Negina Kencono Putri. 2017. The Effect of Tax Understanding, Tax Payness Consciousness, Quality of Tax Service, and Tax Sanctions on Compulsory Tax of SMEs in Banyumas Regency. Jurnal. Fakultas Ekonomi dan Bisnis Universitas Jenderal Soedirman. Purwokerto.

Fatmawati. (2015). Pengaruh Pemahaman Wajib Pajak Atas Peraturan Pemerintah No. 46 Tahun 2013 dan Implementasi Self Assessment System Terhadap Kepatuhan Wajib Pajak Dengan Persepsi Wajib Pajak Sebagai Variabel Moderasi (Studi Empiris Pada Pelaku UMKM Kerajinan Gerabah Kasongan).

Febriana, Anisa. 2019. Pengaruh Penerapan Sistem E-Billing Terhadap Kepatuhan Wajib Pajak dengan Pemahaman Internet sebagai Variabel Moderasi.

Heenkenda, S. (2016). Readiness To Retirement Planning of Estate Sector Employees In Sri Lanka. Munich Personal RePEc Archive Readiness, (72744), 1-18.

Kartikaputri, M.E. 2013. Pengaruh Reformasi Administrasi Perpajakan terhadap Kinerja Pelayanan Perpajakan dan Kepatuhan Wajib Pajak di Kantor Pelayanan Pajak (KPP) Pratama Yogyakarta.

Katadata.co.id. 2018. https:// katadata.co.id/berita/2018/10/31/ditjen-pajak-hanya-15-juta-dari-60-jutapelaku-umkm-bayar-pajak. Diakses pada 30 Oktober 2019 pukul 11.09.

Kementrian Keuangan. 2018. https://www.kemenkeu.go.id/publikasi/artikel-dan-opini/ menciptakanpajak-yang-ramah-untuk-umkm/. Diakses pada 29 Oktober 2019 pukul 10.58.

Marista, M, Betri., dan Fajriana, I. (2014). Pengaruh pemahaman wajib pajak UMKM terhadap pelaksanaan Peraturan Pemerintah No. 46 Tahun 2013 (studi empiris wajib pajak UMKM yang terdaftar di KPP Pratama Palembang Ilir Barat). Jurnal Ekonomi. STIE Multi Data Palembang.

Masruroh, Siti \& Zulaikha. (2013). Pengaruh Kemanfaatan NPWP, Pemahaman Wajib Pajak, Kualitas Pelayanan, Sanksi Perpajakan Terhadap Kepatuhan Wajib Pajak (Studi Empiris pada WPOP di Kabupaten Tegal). Jurusan Akuntansi Fakultas Ekonomika dan Bisnis. Journal Of Accounting. Universitas Diponegoro.

Robbins, S. 2008. Perilaku Organisasi, Jilid I dan II, alih Bahasa : Hadyana Pujaatmaja. Jakarta: Prenhallindo.

Simon, James \& Clinton Alley. 2010. Tax Compliance, Self-Assessment and Tax Administration. Journal of Finance and Management in Public Service. Volume 2 Number 2.

Sugiyono. (2017). Metode Penelitian Bisnis. Bandung:Alfabeta.

Sulistyorini, Murniati. 2017. Pengaruh Penggunaan Sistem Administrasi E-Registration, E-Billing, E-SPT dan E-filing Terhadap Kepatuhan Wajib Pajak (Studi Pada Wajib Pajak Orang Pribadi Di RSUD Dr. Moewardi Surakarta).

Waluyo, 2011. Perpajakan Indonesia. Jakarta: Salemba Empat.

Witono, B. 2008. Pengetahuan Pajak Pada Kepatuhan Wajib Pajak. Jurnal Akuntansi Dan Keuangan, 7(2), 196-208.

Undang-Undang Nomor 28 Tahun 2007 tentang Ketentuan Umum dan Tata Cara Perpajakan. 